\title{
TIME-COMPRESSED SPEECH TEST IN BRAZILIAN PORTUGUESE
}

\author{
Camila Maia Rabelo, Eliane Schochat
}

Rabelo CM, Schochat E. Time-compressed speech test in brazilian portuguese. Clinics. 2007;62(3):261-72.

INTRODUCTION: The time-compressed speech test has existed since the 1970s. It is sensitive for evaluating auditory closure. However, it is not used in Brazil because until recently, it had not been developed in Portuguese.

PURPOSE: To develop a compressed speech test in Portuguese, to apply it to normal-hearing adults, and to verify which of the compressed lists $(50 \%, 60 \%$, or $70 \%)$ is the most appropriate to be part of a set of auditory processing tests.

METHODS: 144 normal-hearing adults, distributed homogeneously between both genders, were assessed. The compressed speech tests were applied using monosyllables and disyllables according to 8 previously established sequences, and the results were compared with respect to the initial ear, to the order of presentation, and to the kind of test.

RESULTS: There were no significant differences between ears. The 50\%, 60\% and 70\% presentation order produced a better average of correct responses than the $70 \%, 60 \%$ and $50 \%$ one. There was a significant difference $(P<.001)$ between the results of the tests comprising lists of monosyllables compared to those comprising disyllables. In both tests (with monosyllables and disyllables) the average of correct responses decreased as the compression increased.

CONCLUSION: The monosyllabic and disyllabic lists with $60 \%$ compression appeared to be more stable than the others, with the average of correct responses around $90 \%$.

KEYWORDS: Speech perception. Hearing tests. Speech discrimination tests. Speech intelligibility.

\section{INTRODUCTION}

The communication process among individuals happens more efficiently when the individual who speaks is able to express himself adequately, and the one who hears is able to understand what is being said.

In the hearing and decoding process of what is being said, an interrelation between the integrity of the peripheral auditory system ("the hearing") and the central auditory system ("the decoding") is observed. The abilities to process the hearing information, the auditory processing abilities, have been observed to be very important for effective communication.

Physiotherapy, Audiology, and Occupational Therapy, Faculty of Medicine, University of São Paulo - São Paulo/SP, Brazil.

Email: cmrabelo@yahoo.com.br

Received for publication on December 01, 2006.

Accepted for publication on January 02, 2007.
Auditory processing studies explore the abilities involved in the interpretation of the sound stimulus and the involvement of several mechanisms of the auditory system that are responsible for processing verbal and nonverbal stimuli. ${ }^{1}$

In 1992, Stecker reported that audiologists have developed unique methods for the evaluation of auditory processing disorders, such that the auditory system functioning may be evaluated in an adequately controlled environment with careful use of the desired stimulus. ${ }^{2}$

Nowadays, there is a great variety of tests for the evaluation of the auditory processing. However, it is difficult to determine which test should be applied in order to obtain a conclusive diagnosis. In the evaluation of the auditory processing, both monotic and dichotic tests are used. ${ }^{3}$

In the international literature, the most frequently used monotic test is the time-compressed speech test. This test is part of a set of tests called low redundancy monaural speech tests that evaluate the closure ability. Auditory clo- 
sure is the ability to recognize the whole (words or messages) when there are omitted parts. ${ }^{4}$

The first studies are from 1957, when Callearo and Lazaroni studied speech intelligibility as affected by speech rate. Their research showed that redundancy of superior structures and of speech message information allows an almost total neutralization of the negative effect of increases in speech rate when such increases remain within modest limits. For greater rate increases, they found the need for an intensity increase in order to attain good discrimination. ${ }^{5}$

Compression methods for the performance of compressed speech tests began to appear in the 1970s. The first one was developed by Beasley et al in 1972, using Northwestern University Auditory Test number 6 word lists (NU-6), which were compressed by the electro-mechanic time compression method. ${ }^{3,6,7}$ The original stimulus was submitted to a number of compressions proportional to an area from $0 \%$ to $70 \%$, at $10 \%$ intervals. It is worth noting that there are other methods for the modification of the speech rate: the rate can be increased or decreased by an alteration in the speaker's speech pattern (articulation pattern) or by recording alteration (analogical or digital). Also, a method used for speech rate increase is to remove portions of the sound wave through an electro-mechanic device, and then gather the resulting segments, presenting them at a normal speed; this accelerates the speech sample.

Since then, the compressed speech material has been used clinically in the evaluation of the speech recognition either in patients with auditory processing disorders or in patients with neurological deficits. ${ }^{8}$

In 2000, Baran and Musiek reported that the compressed speech test had been extensively used in the evaluation of individuals with central auditory nervous system (CANS) pathologies. The compressed speech test stimuli are generally degraded by digital or electro-acoustic modifications of the signal's frequency parameters, time, or intensity characteristics. ${ }^{9}$

Results of research with compressed speech show that the intelligibility is lower when the degree of compression of the stimulus increases. In lower compression bands, $45 \%$ or $50 \%$, the intelligibility is greater and therefore, these are associated with a greater number of correct responses. As the degree of compression increases, the degree of intelligibility decreases proportionally. ${ }^{7,10,11}$

The compression degrees is the most influencing variable on intelligibility. In English, normal speech may retain a satisfactory intelligibility degree even when it is compressed to a point where it is reproduced with $60 \%$ of the normal presentation time. It was concluded that in English, the performance fall was gradual with the increase of the compression from $0 \%$ to $60 \%$, and that the number of re- peated words by segment was, on average, statistically the same for all speeds. At the $60 \%$ compression level, intelligibility of words is satisfactory, and the average of correct responses is stable; however, with an increase of compression to $70 \%$, there is a sudden fall in the average number of correct responses of individuals, showing that stimuli having a $70 \%$ compression are difficult to identify, even for normal individuals. ${ }^{712-14}$ The average for correct responses for each ear considered in the evaluation of Americans is around $82 \%$. Lower scores are considered atypical for adults.

Some research has been carried out in other languages to determine what individual responses would be like in different languages. Research with bilingual individuals showed different when Spanish was compared with Catalan, in contrast to what was found when French was compared with English (languages with different representation). In the study comparing Spanish and Catalan, results showed that the compressed speech in Catalan or in Spanish may be used for training, and that it improves performance in both languages; however, the comparative study between French and English showed that bilingual individuals did not benefit from hearing the test in English when they were tested in French and vice-versa; the difference between the two languages does not cause the presentation of one test to influence the performance in the other. ${ }^{15}$

Research with several compression levels has shown that individuals may learn to better understand stimuli with modified speech speed if they are trained to hear this way. Auditory closure ability can be developed and improved through auditory training, and presentation of compressed speech with lower compression degrees before the higher ones may improve the understanding of modified stimuli, and consequently the average number of correct responses obtained. ${ }^{15-18}$

It is also possible to observe an improvement in the performance of the second ear tested in relation to the first one, which could be explained by the learning of the task through the previous experience of the first ear tested. In the easier condition, individuals use more acoustic clues than in the harder condition; in the harder condition, auditory processing prevails in the auditory closure ability. Decreasing the redundancy makes the compressed speech tests become appropriate for the evaluation of auditory closure. ${ }^{19,20}$

For speech test design, several criteria should be taken into account. In 2002, Mackersie reported that the sensitivity and specificity of the test may be affected by a series of factors, and some of them are under the control of the audiologist. One of them is the digital recording of the speech material. Another factor that can improve the reli- 
ability of the test is increasing the number of items (words). However, this can cause an increase in evaluation time, and therefore researchers have chosen to use monosyllables. ${ }^{21}$ Other influencing factors are the linguistic characteristics of the stimuli and the acoustic clues present in the compressed stimulus ${ }^{22,23}$ as well as the patient's motivation to respond to the test, because the tests should not be too easy or too difficult to the point ceasing to challenge the brain. ${ }^{24}$

The purpose of this study was to elaborate a compressed speech test in Brazilian Portuguese and to apply it to normal-hearing adults. Additionally, an aim of this study was to determine among all lists of words obtained in the 3 compression levels studied $(50 \%, 60 \%$, and $70 \%)$, which would be the most appropriate ones to be included in the set of tests used to evaluate the auditory processing in clinical practice.

The study was performed with adults because they are at an ideal age regarding the maturation of the central auditory nervous system. McPherson (1996) stated that from birth to maturity there are several effects that influence the maturation of auditory pathways that could be observed through the evoked auditory potentials. ${ }^{25}$

A rationale for this study was the lack of a test with Brazilian Portuguese verbal stimuli to evaluate auditory closure ability using the stimulus duration as the degraded parameter. The current battery of tests available in Brazilian Portuguese comprises 2 tests that evaluate this same ability, but one functions through a modification in the stimulus intensity parameters - the speech in noise test-and the other through a modification in the stimulus frequency - the filtered speech test.

Therefore, it is expected that this test could be initially normalized for our population (adults, in this case), and for children of several age groups in the future; it is also expected that it may complement the current battery of evaluation tests of auditory processing of patients who present some kind of disorder in this ability.

\section{PURPOSE}

The purposes of this research were:

1) To elaborate a compressed speech test at 50\%, 60\%, and $70 \%$ compression in Brazilian Portuguese and to apply it to normal-hearing adults. 2) To verify which monosyllabic or disyllabic word list with stimuli time-compressed by $50 \%, 60 \%$, and $70 \%$ is the most appropriate for evaluating the auditory processing.

\section{METHODS}

This study was submitted to and approved by the Research Analysis Ethical Commission of the Hospital das
Clínicas of the University of São Paulo Medical School.

A sample dimensioning study was performed in the Applied Statistical Center, CEA, of the University of São Paulo Institute of Mathematics and Statistics. This study showed that the sample should include of 144 individuals.

Accordingly, 144 individuals were evaluated, divided into 2 groups: 72 women and 72 men, ranging in age from 16 to 33 years. Individuals less than 16 years of age were not included, because they were considered immature from the neurological point of view, and also individuals older than 33 years old were not included because from the neurological point of view, at this point the aging process has already started. The maximum age initially established was 30 years, but due to the difficulty in completing the male sample, the age group was extended 3 years for both groups.

All individuals participated voluntarily, and they had all finished at least secondary school. All signed the Informed Consent Term before the beginning of data collection.

The criteria for the individual selection were as follows: a) age from 16 through 33 years; b) no clinical history of otological or auditory processing, c) basic audiological evaluation (audiometry, speech audiometry, and immittance measures) within normal parameters ${ }^{26}$; d) auditory processing screening within normality. ${ }^{27}$

In the process of patient selection, no IQ tests were performed, nor was the socioeconomic level considered, since according to Almeida et al, there is no significant difference between individuals of different socioeconomic levels; the differences occur as a result of the different stimulation levels received by the individuals during their childhood. In the case of adults, who have already been through this phase, the socioeconomic level no longer influences the performance of auditory processing tests. ${ }^{28}$

The following evaluations were performed: immittance measures, tonal audiometry, speech reception threshold (SRT), and word recognition score (WRS), using the parameters established by Mangabeira Albernaz et al in $1981^{29}$ to assure the integrity of the peripheral system.

From the data obtained with this set of tests, individuals presenting normal results were selected for the administration of the compressed speech test, which was performed in an acoustic cabin.

The compressed speech test that we developed comprised 50 words that were compressed by the electro-mechanical time compression method. The original stimulus, 6 lists with 50 monosyllables and 6 lists with 50 disyllables each (Annex 1), was digitally recorded on a compact disc (CD) in the radio and TV studio of the University of São Paulo Arts and Communication School, at a normal rate; then, the lists underwent compressions varying from 
$50 \%$ to $70 \%$ at intervals of $10 \%$; thus, 2 monosyllabic and 2 disyllabic lists underwent $50 \%$ compression, 2 underwent $60 \%$ compression, and 2 underwent $70 \%$ compression. Each list lasted approximately 5 minutes, and the total evaluation lasted approximately $1 \frac{1}{2}$ hours. Based on the findings of Musiek et al in 1993, the stimulus was presented monaurally at $40 \mathrm{~dB}$ above the speech threshold (SRT) ${ }^{7}$ through a CD player connected to a 2-channel audiometer (GSI - 61), and the participant was asked to repeat what he heard. Participants were also always encouraged to respond, even when they were not sure of the answer. Because all participants were adults, they were told in the beginning of the evaluation that they could interrupt the test when feeling tired or when they felt they were losing attention. First, words were presented through an earphone (TDH - 41) in each ear for each compression level and type of stimulus (monosyllable or disyllable), and the percentage of correct responses for each ear was recorded according to a specific protocol, as was the repeated word, even when it was not correct. According to the American standardization, normal results are declared when scores are above $82 \%$ for each ear. ${ }^{7}$

The performance of the right ear was compared to the performance of the left ear at the different compression levels $(50 \%, 60 \%$, and $70 \%)$ and for the 2 types of word lists (monosyllable and disyllable).

The ANOVA parametric test was used for the statistical analysis.

The confidence interval established for the data analysis was $95 \%$, with the significance level $(P)$ at $0.05(5 \%)$. Results were described according to the average of correct responses, median, standard deviation, and $P<.05$.

In order to avoid possible bias and to determine if there was a difference in beginning the test in each situation, it was decided that each participant would begin the test with a certain ear, a certain stimulus type (monosyllable or di- syllable), and by a certain presentation order (increasing or decreasing).

\section{RESULTS}

Two CDs for the compressed speech tests were produced, one with monosyllabic words and another with disyllabic words. Each CD had 7 tracks, the first with a calibration tone, and the other ones with the lists of words having undergone compressions of $50 \%, 60 \%$, and $70 \%$. Examples of the spectrograms of the monosyllabic word "chão" at the different compressions are seen in Figure 1.

One hundred and forty four individuals were evaluated, 72 men and 72 women. The mean age of these individuals was 24 years (women 22.4 years; men 25.7 years).

The first comparison made was among the averages of correct responses between the ears, right (RE) and left (LE), at the 3 compression levels studied, 50\%, 60\%, and 70\%, for each type of test: compressed speech test with monosyllables (TFC-Mono) and compressed speech test with disyllables (TFC-Bis). No significant difference between the averages of correct responses of the right and left ears at any compression level for either the monosyllable or disyllable list was found (Table 1).

Therefore, and because the ear effect was not significant, these data were combined to double the sample size, and consequently to produce results of higher power.

The number of correct responses among the compression levels for the disyllable list was significantly different $(P<.001)$ from that that for the monosyllable list (Table 2). In all comparisons, the condition with greater compression produced a lower average of correct responses than the condition with lower compression.

The list with lowest average of correct responses (therefore the most difficult one) was the disyllable list that underwent a $70 \%$ compression, and the list with highest av-

Table 1 - Comparison by ANOVA of the results obtained with the right and left ears for the monosyllable and bisyllable tests at the 3 compression conditions

\begin{tabular}{|c|c|c|c|c|c|c|}
\hline \multirow[t]{2}{*}{ Monosyllable } & \multicolumn{2}{|c|}{$50 \%$} & \multicolumn{2}{|c|}{$60 \%$} & \multicolumn{2}{|c|}{$70 \%$} \\
\hline & Right & Left & Right & Left & Right & Left \\
\hline Average(\%) & $45.3(90.6 \%)$ & $45(90.0 \%)$ & $44.1(88.2)$ & $44(88.0 \%)$ & $41.4(82.8 \%)$ & $41.2(82.4 \%)$ \\
\hline Median & 46 & 45 & 44 & 44 & 41 & 41.5 \\
\hline $\mathrm{SD}$ & 2.26 & 2.85 & 2.45 & 2.73 & 3.46 & 3.53 \\
\hline Sample Size & 144 & 144 & 144 & 144 & 144 & 144 \\
\hline $\mathrm{P}$ & \multicolumn{2}{|c|}{.293} & \multicolumn{2}{|c|}{.803} & \multicolumn{2}{|c|}{.511} \\
\hline \multicolumn{7}{|l|}{ Bisyllable } \\
\hline Average $(\%)$ & $47.4(94.8 \%)$ & $47.2(94.4 \%)$ & $46.2(92.4 \%)$ & $45.9(91.8 \%)$ & $34.4(68.8 \%)$ & $34(68.0 \%)$ \\
\hline Median & 48 & 48 & 46.5 & 46.5 & 35 & 34 \\
\hline SD (standard deviation) & 1.90 & 1.95 & 2.35 & 2.64 & 5.44 & 5.57 \\
\hline SampleSize & 144 & 144 & 144 & 144 & 144 & 144 \\
\hline $\mathrm{P}$ & \multicolumn{2}{|c|}{.392} & \multicolumn{2}{|c|}{.278} & \multicolumn{2}{|c|}{.593} \\
\hline
\end{tabular}


Without compression

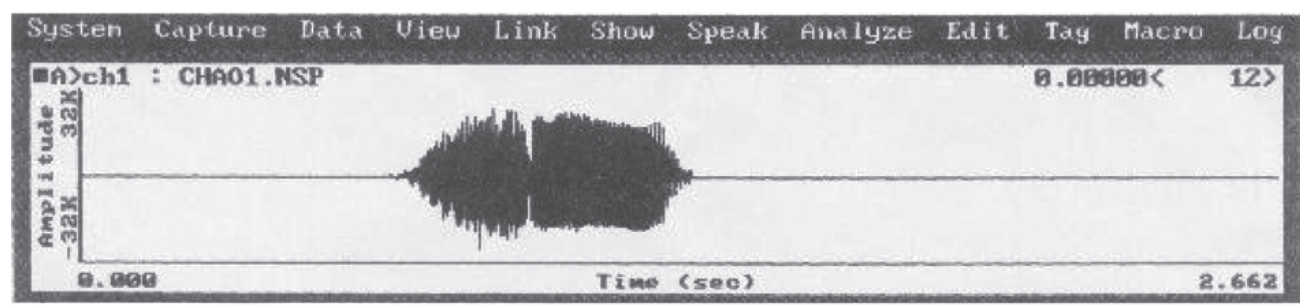

$50 \%$ compression

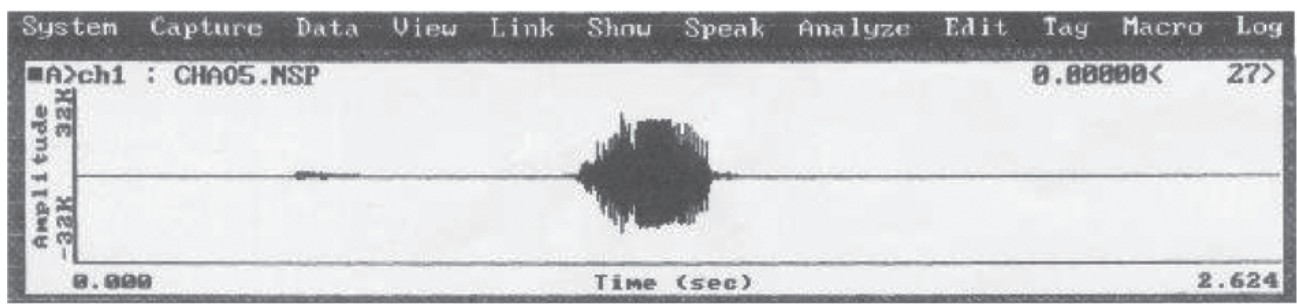

$60 \%$ compression

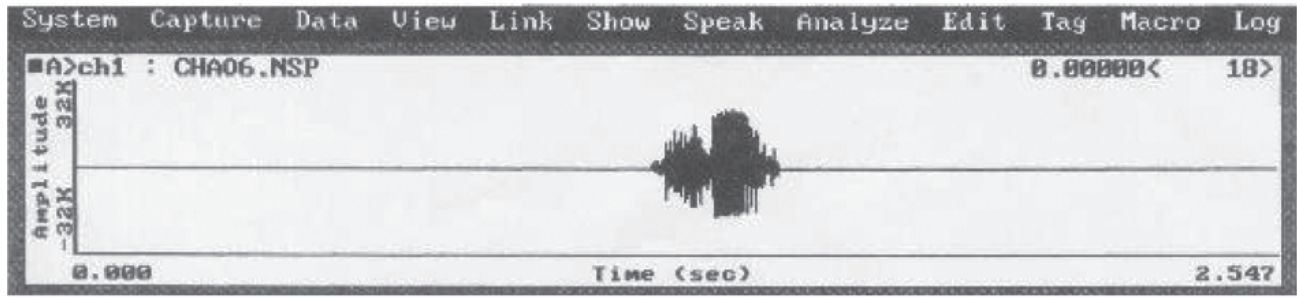

$70 \%$ compression

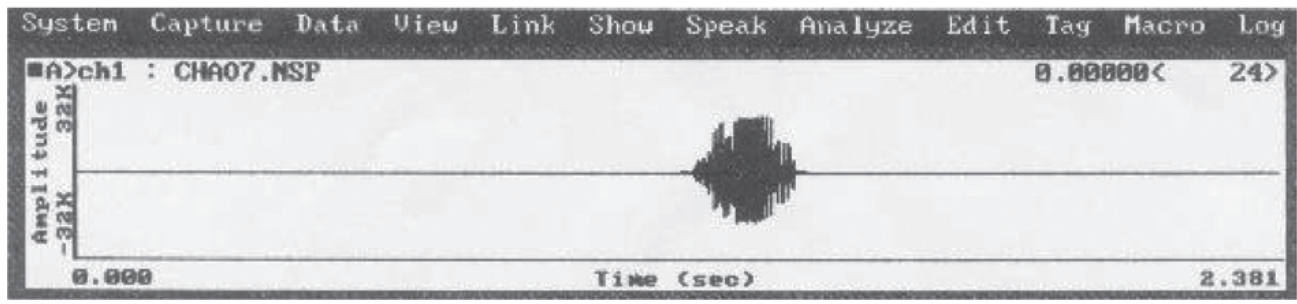

Figure 1 - Spectogram of the monosyllable "chão" (without compression; with 50\%; 60\% and 70\% compression).

erage of correct responses was the disyllable list that underwent a $50 \%$ compression.

At the end of all evaluations, no lack of patient attention was observed, so patient attention appeared not to be a contributing factor to a reduced number of correct responses.

\section{DISCUSSION}

Our findings that there was no significant difference between the ears in either test, agree with those of Baran and Musiek. ${ }^{9}$ This result was expected, because it is known that although the left hemisphere is preferential for language, the reception of a monotic stimulation, such as the compressed speech test, causes the activation of the ipsi- and contralateral pathways of the auditory nervous system; this neutralizes the preference of the right ear relative to the left one and provides a similar performance between both ears. Monotic tests are useful for detecting auditory pathway disorders, but not to locate them, because of the participation of the ipsi- and the contralateral pathways, resulting in a similar performance of the right and the left ears in those tests. ${ }^{9}$

Another studied aspect was the patients' performance according the word lists and the compression conditions applied.

Regarding the monosyllable and disyllable word lists, the disyllable list with $50 \%$ and $60 \%$ time-compression showed a better average (although not tested statistically) of correct responses than the monosyllable lists under the 
Table 2 - Comparison by ANOVA between the averages of correct responses for the word lists (monosyllable and bisyllable) at the 3 compression levels

\begin{tabular}{lcccccc}
\hline Lists & Mono-50 & Mono-60 & Mono-70 & Bis-50 & Bis-60 & Bis-70 \\
\hline Average (\%) & $45.1(90.2 \%)$ & $44(88.0 \%)$ & $41.3(82.6 \%)$ & $47.3(94.6 \%)$ & $46(92.0 \%)$ & $34.2(68.4 \%)$ \\
Median & 46 & 44 & 41 & 48 & 46 & 35 \\
SD & 2.57 & 2.59 & 3.49 & 1.92 & 2.50 & 5.50 \\
Sample Size & 288 & 288 & 288 & 288 & 288 \\
p-value & \multicolumn{2}{c}{$<0.001 *$} & \\
\hline
\end{tabular}

statistically significant

same compression conditions. Therefore, disyllables appeared to be easier to interpret. However, under the $70 \%$ time-compression condition, the inverse occurred, ie, the monosyllables appeared to be easier than the disyllables to interpret.

We had predicted that the test with monosyllables would be more difficult than the test with disyllables. That is because we thought that compression would cause the monosyllables, which are short words, to be less intelligible. However, the universe of Brazilian Portuguese monosyllabic words is more restricted than that of the disyllabic ones, which apparently allowed this test to be easier than the disyllable test at the $70 \%$ time-compression level, since after the distortion caused by the compression disyllabic words produced other words, making intelligibility difficult.

This finding could also be due to the fact that monosyllables present fewer consonantal clusters, and therefore, the chance of the average of correct responses is more elevated. After the compression, the consonantal clusters of the disyllables practically disappeared. This originated several possibilities for other words, which may have increased the number of mistakes in the disyllable lists.

The decrease in intelligibility, or in the ability for auditory closure, that occurs the compressed speech tests is due to the loss of phonologic information that makes different words, in addition to compromising their intelligibility. ${ }^{15,22}$

A preference for the use of monosyllables was found in the reviewed literature ${ }^{8,21}$ Monosyllable tests were preferred especially in clinical practice, because they are simple to administer, requiring little time, and because they are based on extensive normative data, especially in English. Furthermore, they are less redundant, which somehow minimizes the lexical and semantic influence. This influence is a factor that should be taken into account mainly in the speech tests, because despite the phonemic discrimination being determinant in this type of test, the cognitive and linguistic aspects cannot be disregarded, nor should the acoustic characteristics of words and their access to the mental lexical in the performance of individuals in the test. ${ }^{21}$

The design of a test with words requires some consideration, such as including words that are part of the vo- cabulary of the majority of the population, a broad distribution of phonemes, and easily understood words with equal intelligibility. Another concern is with the material recording, so that the sound quality is adequate and not another factor to prejudice the intelligibility. It is conceded, then, that even though the intent is for great control over the factors that interfere in the message, the lists are hardly perfect and not quite ideal. ${ }^{21}$

For the design of the time-compressed speech test and based on the literature on tests with words, we used balanced lists with words that are broadly used in audiological tests in order to present good quality after compression.

Our analysis was chosen in order to determine which list would be more appropriate for further use in the evaluation of auditory processing in clinical practice. Accordingly, based on our comparisons, it would be possible to find which of the 6 lists would be the better one to apply in evaluation of patients with suspicion of auditory processing disorders, without being too easy or too difficult. Thus, the aim was to obtain a list with good sensitivity and specificity to be used in evaluations.

In both compressed speech tests, those with monosyllables and with disyllables, the intelligibility was higher in the less compressed lists and lower in the more compressed ones.

Some degrees of compression are really more intelligible than others, since less compression, (such as 50\%), does not notably compromise intelligibility. Under these conditions, the messages (words) still have supplementary information that increases the intelligibility and facilitates the recognition of words. ${ }^{16}$

The average number of correct responses was lowest for the disyllable list with a $70 \%$ time-compression. Some factors collaborated for the lower intelligibility in the $70 \%$ timecompression, and among them was the fact that the individual has to form, test, and reject several hypotheses in the search for the correct word, which is in agreement with the findings of Friedman and Johnson; ${ }^{10}$ additionally, participants have to be more alert and vigilant during the evaluation, since the most compressed lists present increased distortion and decreased redundancy. Katz and Wilde (1985), ${ }^{12}$ also reported 
this finding in their study. It was also found in the comparison between the differences in the averages of correct responses of the monosyllable and disyllable lists in each compression degree, that the greater difference was between the lists of words with $70 \%$ compression.

The list with highest average of correct responses was the disyllable list with $50 \%$ time-compression, which was thus the easiest list and the one with the highest degree of intelligibility.

Therefore, the results obtained in this study are similar to those found in the literature, ${ }^{7,13,14,17}$ that report decreased intelligibility with the increase of time-compression, a gradual fall of the averages of correct responses at compression levels until the $60 \%$ level, and lower averages of correct responses at $70 \%$ time-compression.

In auditory training programs, the average of correct responses should be between $30 \%$ and $70 \%$ to maintain the patient's motivation, ie, so that the test is not too easy nor too difficult to the point of not maintaining a challenge to the brain. ${ }^{24}$

Based on the findings of the study, the most stable list was the one with $60 \%$ compression for both types of stimuli, because at this compression level, the average of correct responses was around $90 \%$, and it resulted in the lowest standard deviation, denoting stability in the results.

These findings agree with those in the literature, ${ }^{7,13}$ where the average of correct response in the most stable compressions was reported to be around $82 \%$ in normal hearing adults.
Thus, we conclude that the $60 \%$ time compression, either with mono- or disyllable lists, is the most adequate condition to be used in the future in evaluations of auditory processing in adults, because it presented an average of correct responses above the average obtained at the $70 \%$ time-compression level, and it produced less variability than $50 \%$ time compression.

\section{CONCLUSIONS}

The results of data analysis showed that it was possible to design two CDs, one with the compressed speech test with monosyllabic words and another one with disyllabic words in Brazilian Portuguese, with compressions of $50 \%, 60 \%$, and $70 \%$. In the comparison between the monosyllable and disyllable lists, and between the compression conditions, it can be concluded that the most stable list was the $60 \%$ compression one for both types of stimuli, because at this time-compression level, the average of correct response was around $90 \%$ and the variability was lowest. There was no significant difference between the performance of the right ear or the left ear for the time-compressed speech test with monosyllables (TFC-M), or for the timecompressed speech test with disyllables (TFC-D).

\section{ACKNOWLEDGMENTS}

This study was supported by FAPESP.

\section{RESUMO}

Rabelo CM, Schochat E. Teste de fala comprimida em português. Clinics. 2007;62(3):261-72.

INTRODUÇÃO: O teste de fala comprimida existe há mais de 30 anos, é sensível para avaliar o fechamento auditivo, porém não é usado no Brasil, já que, até os dias de hoje, ainda não havia sido desenvolvido para o português do Brasil.

OBJETIVOS: Elaborar um teste de fala comprimida em português e aplicá-lo em adultos normo-ouvintes, verificar qual das listas comprimidas $(50,60$ e 70\%) é a mais apropriada para integrar o grupo de testes de Processamento Auditivo.
MÉTODOS: Foram avaliados 144 indivíduos adultos, distribuídos homogeneamente entre os gêneros masculino e feminino. Foram aplicados os testes de fala comprimida com monossílabos e dissílabos, de acordo com oito seqüências previamente estabelecidas para em seguida comparar os resultados de acordo com a orelha inicial, ordem de apresentação e tipo de teste.

RESULTADOS: Não houve diferença estatisticamente significante entre as orelhas, a ordem crescente de apresentação mostrou uma média de acertos melhor que a decrescente, os testes com monossílabos apresentaram 
maior média de acertos que os dissílabos e em ambos os testes (com monossílabos e com dissílabos) a média de acertos diminui com o aumento da compressão.

CONCLUSÃO: As listas de monossílabos e dissílabos com compressão de $60 \%$ mostraram-se mais estáveis que as outras, com média de acerto em torno de $90 \%$.

UNITERMOS: Percepção de fala; Testes auditivos; Testes de discriminação da fala; Inteligibilidade da fala.

\section{REFERENCES}

1. Jerger J, Musiek FE. Report of the Consensus Conference on the diagnosis of auditory processing disorders in school-aged children. $\mathrm{J}$ Am Acad Audiol. 2000;11:467-74.

2. Stecker NA. Central auditory processing: implications in audiology. In: Katz J, Stecker NA, Henderson D. Central auditory processing: a transdisciplinary view. St. Louis: Mosby Year Book; 1992; p. 117. 27.

3. Schochat E. Processamento auditivo: revisão de literatura. Rev. Bras. Atual. Otorrinolaringol. 1998;5: 24-31.

4. Rees NS. Saying more than know: Is auditory processing disorder a meaningful concept? In: Keith RW. Central Auditory anda language disorders in children. Softcover ed., California, College-Hill Press; 1982; p. 94-120.

5. Calearo C, Lazzaroni A speech intelligibility in relation to the speed of message. Laryngoscope. 1957;67:410-9.

6. Beasley D, Schwimmer S, Rintelmann W. Intelligibilty of timecompressed CNC monosyllables. J Speech Hear Res. 1972;15:340-50.

7. Musiek FE, Baran JA, Pinheiro ML. Neuroaudiology: case studies. San Diego: Singular; 1993; p. 7-28: Behavioral and electrophysiological test procedures.

8. Mueller HG. Monosyllabic procedures. In: Katz J. Handbook of clinical audiology. 3rd. Baltimore: Williams \& Wilkins; 1985; p. 355-82.

9. Baran JA, Musiek FE. Avaliação comportamental do sistema nervoso auditivo central. In: Musiek, FE; Rintelmann, WF. Perspectivas atuais em avaliação auditiva. São Paulo: Manole; 2000; p. 371-409.
10. Friedman HL, Johnson RL. Compressed speech: correlates of listening ability. J Commun. 1968;18:205-18.

11. Wingfield A, Nolan KA. Spontaneous segmentation in normal and in time compressed speech. Percept Psychophys. 1980;28:97-102.

12. Katz J, Wilde L. Auditory perceptual disorders in children. In: Katz J. Handbook of clinical audiology. 3rd. Baltimore: Williams \& Wilkins; 1985; p. 664-88.

13. Wilson, RH, Peece, JP, Salamon, DL, Sperry, JL, Bornstein, SP. Effects of time compression plus reverberation on the intelligibility of Northwestern University auditory test no. 6. J Am Acad Audiol. 1994;5:269-77.

14. Humes, LE. Do "auditory processing" tests measure auditory processing in the elderly? Ear and Hearing. 2005;26;109-19.

15. Pallier C, Sebastian-Gallés N, Dupoux E, Christophe A, Mehler J. Perceptual adjustment to time-compressed speech: a cross-linguistic study. Mem Cognit. 1998;26: 844-51.

16. Orr DB. Time compressed speech - a perspective. J Commun. 1968;18:288-92.

17. Beasley DS, Maki JE, Orchik DJ. Children's perception of timecompressed speech on two measures of speech discrimination. J Speech Hear Disord. 1976;41:216-25.

18. Wilson RH, Bell TS, Koslowski JA. Learning effects associated with repeated word-recognition measures using sentence material. J Rehabil Res Dev. 2003;40:329-36. 
19. Schochat E. Percepção de fala: presbiacusia e perda auditiva induzida pelo ruído [tese]. São Paulo: Faculdade de Filosofia, Letras e Ciências Humana, Universidade de São Paulo; 1994.

20. Chermak, GD, Musiek, FE. Central auditory processing disorders: new perspectives. San Diego: Singular Publishing Group, Inc; 1997; p. 10927: Behavioral central auditory tests.

21. MacKersie CL. Tests of speech perception abilities. Curr Opin Otolaryngol Head Neck Surg. 2002;10(5):392 -7.

22. Sebastián-Gallés N, Dupoux E, Costa A, Mehler J. Adaptation to timecompressed speech: phonological determinants. Percept Psychophys. 2000;62:834-42.

23. Gordon - Salant S, Fitzbbons PJ. Sources of age-related recognition difficulty for time-compressed speech. J Speech Lang Hear Res. 2001;44:709-19.

24. Musiek FE, Schochat E. Auditory training and central auditory processing disorders - a case study. Semin Hearing. 1998;19:357-66.
25. McPherson DL. Late potencials of the auditory system. London: Singular; 1996. p.75-100: Clinical aplication of the long latency auditory evoked potencials.

26. American national standards institute. American national standards specifications for audiometers. New York: ANSI; S 3.6, 1969.

27. Pereira LD. Processamento auditivo central: abordagem passo a passo. In: Pereira LD, Schochat E. Processamento auditivo central - manual de avaliação. São Paulo: Editora Lovise; 1997; p. 49-60.

28. Almeida CC, Lopes CC, Macedo LM, Gadel MT, Costa MC, Pereira LD. Influência do nivel sócio-econômico e cultural e da estimulação auditiva nas habilidades do processamento auditivo . Fono Atual. 1997: $1: 12.17$

29. Mangabeira-Albernaz P, Mangabeira-Albernaz PL, MangabeiraAlbernaz LG, Mangabeira-Albernaz PF. Otorrinolaringologia prática. 10a. São Paulo: Sarvier; 1981.

30. Santos TM, Russo IP. A prática da audiologia clínica. São Paulo: Cortez; 1986; p. 73-88: Logoaudiometria.

Name:

Age:

Date:

List 01 and list $02-50 \%$ compression

Compressed speech test (monosyllables)

\begin{tabular}{|c|c|c|c|c|c|}
\hline & List - $01(50 \%)$ & List - $02(50 \%)$ & & List - 01(50\%) & List $-02(50 \%)$ \\
\hline & Right & Left & & Right & Left \\
\hline 01 & BOM & PÉ & 26 & PÉ & MEU \\
\hline 02 & PÓ & TEU & 27 & BEM & TOM \\
\hline 03 & DÓ & CAL & 28 & DAR & QUAL \\
\hline 04 & TÃO & BAR & 29 & TEU & BOI \\
\hline 05 & QUEM & DOM & 30 & QUER & DEU \\
\hline 06 & GOL & GÁS & 31 & GÁS & GOL \\
\hline 07 & FUI & FIZ & 32 & FÉ & FAZ \\
\hline 08 & SOL & CHÁ & 33 & VOU & SAL \\
\hline 09 & ZÉ & SOL & 34 & SIM & CHÃO \\
\hline 10 & CRUZ & VOZ & 35 & CRER & MAR \\
\hline 11 & RIM & ZÁS & 36 & BIS & NEM \\
\hline 12 & NÃO & GIZ & 37 & DOR & GIM \\
\hline 13 & MEU & MÃO & 38 & JUZ & LER \\
\hline 14 & JÁ & NÓ & 39 & RÉU & $\mathrm{R} \tilde{\mathrm{A}}$ \\
\hline 15 & SUL & NHÁ & 40 & LUA & CRER \\
\hline 16 & COR & LAR & 41 & SOM & GEL \\
\hline 17 & PUS & LHA & 42 & NEM & VÉU \\
\hline 18 & BAR & RIR & 43 & MEL & JUZ \\
\hline 19 & TREM & BRIM & 44 & ZÁS & JÁ \\
\hline 20 & LÃ & GRÃO & 45 & CHÃO & VAI \\
\hline 21 & ROL & POR & 46 & RIR & LUZ \\
\hline 22 & QUIS & DOR & 47 & LEI & FEL \\
\hline 23 & $\mathrm{NU}$ & PÃO & 48 & FIM & FLOR \\
\hline 24 & CÉU & BEM & 49 & TER & CÁ \\
\hline \multirow[t]{2}{*}{25} & VI & CÃO & 50 & VOZ & TIL \\
\hline & Score & & $\%$ & & \\
\hline
\end{tabular}

Score:

Right $=$

Left $=$ 
List 03 and list $04-60 \%$ compression

\begin{tabular}{|c|c|c|c|c|c|}
\hline & List $-03(60 \%)$ & List - $04(60 \%)$ & & List $-03(60 \%)$ & List $-04(60 \%)$ \\
\hline & Right & Left & & Right & Left \\
\hline 01 & PÁ & COR & 26 & PAI & FIO \\
\hline 02 & TOM & LHE & 27 & MAR & DOR \\
\hline 03 & COR & JÁ & 28 & QUE & TIL \\
\hline 04 & BOM & ZÁS & 29 & BIS & VOU \\
\hline 05 & FIZ & NHÔ & 30 & DAR & LHA \\
\hline 06 & GÁS & TIA & 31 & GIZ & MAR \\
\hline 07 & FIO & CHÁ & 32 & FAZ & VAI \\
\hline 08 & CHÁ & TAL & 33 & SEU & POR \\
\hline 09 & SIM & NÃO & 34 & CHÃO & NÓS \\
\hline 10 & VÃO & MAL & 35 & MIM & DOM \\
\hline 11 & ZÁS & FIZ & 36 & NÃO & NEM \\
\hline 12 & JÁ & LER & 37 & RUM & TEU \\
\hline 13 & MAL & CAL & 38 & LUA & GIZ \\
\hline 14 & SOL & DIA & 39 & RIR & NHA \\
\hline 15 & NHÔ & VÃO & 40 & CRU & RIO \\
\hline 16 & LER & SOL & 41 & GRÃO & PÉ \\
\hline 17 & LHE & TRÊS & 42 & CÉU & TRAZ \\
\hline 18 & RÉU & PAU & 43 & MÊS & SAL \\
\hline 19 & TRÊS & PÁ & 44 & JUZ & CÉU \\
\hline 20 & GRAU & RÉU & 45 & VEM & CHÃO \\
\hline 21 & TIA & GÁZ & 46 & LAR & LAR \\
\hline 22 & CAL & DAR & 47 & MEL & BAR \\
\hline 23 & DIA & GRAU & 48 & DOR & ZÉ \\
\hline 24 & PAU & TOM & 49 & CÃO & CÃO \\
\hline \multirow[t]{2}{*}{25} & TAL & VOZ & 50 & TEU & GRÃO \\
\hline & Score & & $\%$ & & \\
\hline
\end{tabular}

Score:

Right $=$

Left $=$

List 05 and list $06-70 \%$ compression

\begin{tabular}{|c|c|c|c|c|c|}
\hline & List $-05(70 \%)$ & List - $06(70 \%)$ & & List $-05(70 \%)$ & List $-06(70 \%)$ \\
\hline & Right & Left & & Right & Left \\
\hline 01 & RIO & PÁ & 26 & VOZ & PÉ \\
\hline 02 & FIO & TOM & 27 & GOL & TEU \\
\hline 03 & LHA & COR & 28 & CHÁ & MEL \\
\hline 04 & LAR & GÁZ & 29 & NHÔ & BAR \\
\hline 05 & CHÃO & FIZ & 30 & JÁ & GIM \\
\hline 06 & TRAZ & SOL & 31 & NÃO & GOL \\
\hline 07 & GÁZ & CHÁ & 32 & TOM & FIO \\
\hline 08 & CAL & VOZ & 33 & LER & SAL \\
\hline 09 & VOU & VÃO & 34 & PAU & CHÃO \\
\hline 10 & NEM & ZÁS & 35 & DAR & VOU \\
\hline 11 & DOM & JÁ & 36 & ZÁS & GIZ \\
\hline 12 & GIZ & MAL & 37 & TIA & ZÉ \\
\hline 13 & CÃO & NÃO & 38 & GRAU & MAR \\
\hline 14 & GRÃO & NHÔ & 39 & DIA & NÓS \\
\hline 15 & NÓS & LER & 40 & LHE & NHÁ \\
\hline 16 & SAL & LHE & 41 & TAL & LAR \\
\hline 17 & MEL & RÉU & 42 & PÁ & LHA \\
\hline 18 & TEU & TRÊS & 43 & GIM & RIO \\
\hline 19 & BAR & GRAU & 44 & VÃO & TRAZ \\
\hline 20 & ZÉ & TIA & 45 & FIZ & GRÃO \\
\hline 21 & MAR & CAL & 46 & COR & POR \\
\hline 22 & POR & DIA & 47 & MAL & DOM \\
\hline 23 & CÉU & PAU & 48 & RÉU & NEM \\
\hline 24 & NHÁ & TAL & 49 & TRÊS & CÃO \\
\hline \multirow[t]{2}{*}{25} & PÉ & DAR & 50 & SOL & CÉU \\
\hline & Score & & $\%$ & & \\
\hline
\end{tabular}

Score:

Right $=$

Left $=$ 
Name:

Age:

Date:

List 01 and list $02-50 \%$ compression

Compressed speech test (bisyllables)

\begin{tabular}{|c|c|c|c|c|c|}
\hline & List $-01(50 \%)$ & List - $02(50 \%)$ & & List $-01(50 \%)$ & List $-02(50 \%)$ \\
\hline & Right & Left & & Right & Left \\
\hline 01 & PANO & BAILE & 26 & BAILE & PANO \\
\hline 02 & TINTA & CARA & 27 & CARA & TINTA \\
\hline 03 & CORTE & DONO & 28 & DONO & CORTE \\
\hline 04 & $\mathrm{BICHO}$ & GRITO & 29 & GRITO & $\mathrm{BICHO}$ \\
\hline 05 & DENTE & PAPO & 30 & PAPO & DENTE \\
\hline 06 & GOLE & CANTO & 31 & CANTO & GOLE \\
\hline 07 & FERRO & CHEFE & 32 & CHEFE & FERRO \\
\hline 08 & CINCO & SOLA & 33 & SOLA & CINCO \\
\hline 09 & CHINA & CARRO & 34 & CARRO & CHINA \\
\hline 10 & MARCA & GELO & 35 & GELO & MARCA \\
\hline 11 & NOSSA & POUCO & 36 & POUCO & NOSSA \\
\hline 12 & BANHO & REDE & 37 & REDE & BANHO \\
\hline 13 & ROLHA & LOGO & 38 & LOGO & ROLHA \\
\hline 14 & RATO & NEGRO & 39 & NEGRO & RATO \\
\hline 15 & CREDO & SONHO & 40 & SONHO & CREDO \\
\hline 16 & GRADE & MODA & 41 & MODA & GRADE \\
\hline 17 & PRIMO & FILHO & 42 & FILHO & PRIMO \\
\hline 18 & ASA & CHIFRE & 43 & CHIFRE & ASA \\
\hline 19 & GENTE & LIVRE & 44 & LIVRE & GENTE \\
\hline 20 & VIDRO & GATO & 45 & GATO & VIDRO \\
\hline 21 & LAÇO & JOVEM & 46 & JOVEM & LAÇO \\
\hline 22 & ALTO & NUNCA & 47 & NUNCA & ALTO \\
\hline 23 & CLARO & TRAÇO & 48 & TRAÇO & CLARO \\
\hline 24 & TIGRE & ZONA & 49 & ZONA & TIGRE \\
\hline \multirow[t]{2}{*}{25} & TOMBO & VOLTA & 50 & VOLTA & TOMBO \\
\hline & Score & & $\%$ & & \\
\hline
\end{tabular}

Score:

Right $=$

Left $=$

List 03 and list $04-60 \%$ compression

\begin{tabular}{|c|c|c|c|c|c|}
\hline & List - $03(60 \%)$ & List - $04(60 \%)$ & & List $-03(60 \%)$ & List $-04(60 \%)$ \\
\hline & Right & Left & & Right & Left \\
\hline 01 & BRAÇO & PATO & 26 & PATO & BRAÇO \\
\hline 02 & CASA & TELA & 27 & TELA & CASA \\
\hline 03 & DISCO & CAMA & 28 & CAMA & DISCO \\
\hline 04 & FACA & BOLA & 29 & BOLA & FACA \\
\hline 05 & JARRA & DATA & 30 & DATA & JARRA \\
\hline 06 & PAGO & GOTA & 31 & GOTA & PAGO \\
\hline 07 & TETO & FONTE & 32 & FONTE & TETO \\
\hline 08 & RODA & CHEIO & 33 & CHEIO & RODA \\
\hline 09 & CEDO & SANTO & 34 & SANTO & CEDO \\
\hline 10 & QUILO & VALSA & 35 & VALSA & QUILO \\
\hline 11 & LAÇO & ZEBRA & 36 & ZEBRA & LAÇO \\
\hline 12 & BRILHO & GEMA & 37 & GEMA & BRILHO \\
\hline 13 & NADA & MALA & 38 & MALA & NADA \\
\hline 14 & LINHA & NARIZ & 39 & NARIZ & LINHA \\
\hline 15 & MOLA & MANHÃ & 40 & MANHÃ & MOLA \\
\hline 16 & CAMPO & LAGO & 41 & LAGO & CAMPO \\
\hline 17 & TOMBO & CALHA & 42 & CALHA & TOMBO \\
\hline 18 & DROGA & CARO & 43 & CARO & DROGA \\
\hline 19 & SALTO & FAROL & 44 & FAROL & SALTO \\
\hline 20 & LENÇO & GRITO & 45 & GRITO & LENÇO \\
\hline 21 & CHAVE & PLACA & 46 & PLACA & CHAVE \\
\hline 22 & CRAVO & VIDRO & 47 & VIDRO & CRAVO \\
\hline 23 & VIDA & BRANCO & 48 & BRANCO & VIDA \\
\hline 24 & NUVEM & BLUSA & 49 & BLUSA & NUVEM \\
\hline \multirow[t]{2}{*}{25} & ZELO & FLAUTA & 50 & FLAUTA & ZELO \\
\hline & Score & & $\%$ & & \\
\hline
\end{tabular}

Score:

Right $=$

Left $=$ 
List 05 and list $06-70 \%$ compression

\begin{tabular}{|c|c|c|c|c|c|}
\hline & List $-05(70 \%)$ & List $-06(70 \%)$ & & List - $05(70 \%)$ & List $-06(70 \%)$ \\
\hline & Right & Left & & Right & Left \\
\hline 1 & POSTE & PADRE & 26 & PADRE & POSTE \\
\hline 02 & TOCA & TONTO & 27 & TONTO & TOCA \\
\hline 03 & COLA & QUERO & 28 & QUERO & COLA \\
\hline 04 & VIDA & BOTA & 29 & BOTA & VIDA \\
\hline 05 & DAMA & DADO & 30 & DADO & DAMA \\
\hline 06 & MANHÃ & GOLA & 31 & GOLA & MANHÃ \\
\hline 07 & FITA & FURO & 32 & FURO & FITA \\
\hline 08 & CHUVA & SANTO & 33 & SANTO & CHUVA \\
\hline 09 & CENTO & MARCHA & 34 & MARCHA & CENTO \\
\hline 10 & VENTO & MUNDO & 35 & MUNDO & VENTO \\
\hline 11 & ZONA & NEVE & 36 & NEVE & ZONA \\
\hline 12 & GELO & SENHA & 37 & SENHA & GELO \\
\hline 13 & MATA & CALHA & 38 & CALHA & MATA \\
\hline 14 & NINHO & RISO & 39 & RISO & NINHO \\
\hline 15 & MINHA & CRIA & 40 & CRIA & MINHA \\
\hline 16 & LOGO & GROSSO & 41 & GROSSO & LOGO \\
\hline 17 & MALHA & CHAVE & 42 & CHAVE & MALHA \\
\hline 18 & FAROL & ZANGA & 43 & ZANGA & FAROL \\
\hline 19 & PRETO & JOVEM & 44 & JOVEM & PRETO \\
\hline 20 & GRAMA & VELA & 45 & VELA & GRAMA \\
\hline 21 & BLOCO & LAGO & 46 & LAGO & BLOCO \\
\hline 22 & CLASSE & SALTO & 47 & SALTO & CLASSE \\
\hline 23 & DRAMA & CLERO & 48 & CLERO & DRAMA \\
\hline 24 & PLANO & MAGRO & 49 & MAGRO & PLANO \\
\hline \multirow[t]{2}{*}{25} & TRAVA & TANGO & 50 & TANGO & TRAVA \\
\hline & Score & & $\%$ & & \\
\hline
\end{tabular}

Score:

Right $=$

Left $=$ 